\title{
Da indiferença e da aporofobia à hospitalidade: uma reflexão antropológica diante da crise migratória
}

\author{
From indifference and aporophobia to hospitality: an \\ anthropological reflection in the face of migration crisis
}

LÚCIA PEDROSA-PÁDUA a

\section{Resumo}

A crise migratória adquire contornos dramáticos e universais nos dias de hoje, em que o sofrimento de milhões de pessoas contrasta com a indiferença, o fechamento e o ódio diante dos migrantes e refugiados. O tema adquire relevância para a Igreja e a sociedade com a tomada de posição firme e solidária do Papa Francisco em defesa dos refugiados e seus direitos. Dentre as causas da indiferença e do ódio aos migrantes e refugiados ressaltamos a aporofobia, ou rejeição aos pobres, segundo a filósofa Adela Cortina, e a insegurança existencial, segundo o sociólogo Zygmunt Bauman. Na tradição judaicocristã, a relação com o migrante e o refugiado passa pela hospitalidade. Fiel a esta tradição, Francisco realiza o apelo a novas lógicas de desenvolvimento e a nova atitude diante daqueles que buscam oportunidades de vida. Em resposta a estes apelos, uma espiritualidade hospitaleira deverá ser de abertura, superação do sentimento aporófobo e de rejeição, escuta e aproximação de horizontes.

Palavras-chave: Aporofobia. Hospitalidade. Migrantes. Refugiados.

\section{Abstract}

Nowadays, the migratory crisis acquires dramatic and universal contours. The suffering of millions of people is in contrast to indifference, closing of the people and hatred toward migrants and refugees. This acquires relevance for the Church and society with the firm and solidarity stance of Pope Francisco in defense of refugees and their rights. Among the causes of indifference and hatred of migrants and refugees we emphasize the aporophobia, or rejection to the poor, according to the philosopher Adela Cortina, and the existential insecurity, according to sociologist Zygmunt Bauman. In the Jewish-Christian tradition, the relationship with the migrant and refugee goes through hospitality. Faithful to this

\footnotetext{
a Pontifícia Universidade Católica do Rio de Janeiro (PUC-Rio), Rio de Janeiro, RJ, Brasil. Doutora em Teologia Sistemático-pastoral, e-mail: Ipedrosa@puc-rio.br
} 
tradition, Francisco calls for new logic of development and a new attitude towards those who seek opportunities of life. In response to these calls, a hospitable spirituality should be, overcoming aporophobic feelings, listening and approaching horizons.

Keywords: Aporophobia. Hospitality. Migrants. Refugees. Theology.

\section{Introdução}

Ao visitar a ilha de Lampedusa em 2013 e denunciar a "globalização da indiferença" com relação aos refugiados, o Papa Francisco colocou a solidariedade diante da crise migratória no centro dos desafios da humanidade e critério para a vivência de um cristianismo autêntico.

Francisco figura entre os profetas que, com clarividência, preveem a urgência de uma mudança de rota nas lógicas que regem o desenvolvimento globalizado, com vistas à redução do sofrimento no mundo e ao engrandecimento da jornada humana nesta terra, em fidelidade ao Deus revelado em Jesus Cristo.

O presente artigo, de caráter interdisciplinar, busca visibilizar e refletir sobre as dinâmicas de rejeição aos migrantes e refugiados, com o objetivo de superá-las, rumo à construção de uma sociedade e uma Igreja mais acolhedoras e hospitaleiras, capazes de ir ao encontro das necessidades de quem mais sofre. De fato, as lógicas xenófobas e aporófobas atuam como poderosos entraves à solidariedade e à justiça e, consequentemente, à evangelização e à vivência da fé viva. A teologia auxilia esta reflexão ao jogar a luz e o frescor de uma Palavra que ilumina os obscuros caminhos do egoísmo humano e ao anunciar uma Presença que anima os corações paralisados pela indiferença ou pela dor.

Iniciaremos com uma panorâmica sobre a extensão do drama humano dos refugiados e migrantes e as dificuldades de acolhida que eles enfrentam em todos os continentes. A seguir, propomos duas perspectivas de análise da indiferença e ódio a esses grupos: a aporofobia, segundo a filósofa Adela Cortina, e a insegurança existencial, segundo o sociólogo Zygmunt Bauman. Num terceiro momento, faremos um aprofundamento bíblico teológico a respeito do tema e veremos como Deus continua a convocar à hospitalidade. Em perspectiva teológica, seguimos com a análise do apelo de Francisco a 
novas lógicas de desenvolvimento e de relações. Finalmente, diante de todo este trajeto, indicamos alguns aspectos que nos parecem importantes para uma espiritualidade hospitaleira, em que haja abertura, superação do sentimento aporófobo, escuta e aproximação de horizontes.

\section{Uma situação dramática e globalizada}

Os dados de 2018 impressionam. Segundo a ACNUR, Alto Comissariado das Nações Unidas para Refugiados, 37.000 pessoas, por dia, são obrigadas a fugir de suas casas por causa de guerras, conflitos e perseguições. Há hoje 70,8 milhões de pessoas nesta situação (ACNUR, 2019).

Trata-se de um tema sensível e espinhoso. Os programas políticos dos países tendem a proteger fronteiras e espaços garantidos. Partidos xenófobos e racistas ganham espaços na Europa, nos EUA e também na América Latina e Caribe. No entanto, nada disso altera o aumento exponencial dos migrantes e refugiados em escala global.

Na Europa, entre 2014 e 2015, o número deles multiplicou dez vezes, especialmente procedentes da guerra da Síria e Iraque e do desastre econômico e político de países africanos (PILARIO; RECK, 2015, p. 660-661). Ataques jihadistas pioraram a situação. Em vários países desenvolveram-se grupos civis nacionalistas, críticos aos políticos socialdemocratas. Houve ascensão das extremas direitas e aumento do populismo. Países recebem um número de refugiados inferior às suas potencialidades geográficas e econômicas. Tudo isto mostra o enfraquecimento da solidariedade europeia e o desenvolvimento de um egoísmo inumano.

As regiões da Ásia e do Pacífico enfrentam o deslocamento dos afegãos e dos rohinyás, muçulmanos rechaçados e perseguidos em Myanmar. São milhares de barcos desaparecidos no mar, com homens e mulheres famintos à mercê das circunstâncias climáticas, a enfrentar a indiferença, a insensibilidade e a lentidão das iniciativas (PILARIO; RECK, 2015, p. 662).

A África, por sua vez, além da migração externa, apresenta intensa dinâmica migratória interna. Muitos países, como Moçambique, são, ao mesmo tempo, emissores, receptores e corredores de passagem. Alguns 
deles, como o Sudão do Sul, são responsáveis por alguns dos mais elevados índices emigratórios do mundo. Os deslocamentos são produzidos por desestabilizações políticas, conflitos armados, trivialização da violência, perseguições étnicas e religiosas, problemas ambientais e climáticos. O fluxo migratório interno tem aumentado progressivamente nos últimos anos, majoritariamente migrações forçadas e de refugiados (GONÇALVES PATRICIO, 2018, p. 24-27).

Na América Latina, os dados da ACNUR mostram como o número de refugiados cresceu com a crise venezuelana - foram eles, em 2018, o grupo com maior número de solicitações de refúgio no mundo, ultrapassando os pedidos dos afegãos, sírios e iraquianos (ACNUR, 2019). Em países como a Colômbia, há milhões de refugiados internos, deslocados pela violência, vítimas de conflitos entre atores armados ilegais (guerrilhas, paramilitares e cartéis das drogas), forçados a migrar dentro do território nacional, a abandonar seu local de residência ou atividade econômica habitual (MENDOZA, 2018, p. 244).

No Brasil, 2018 foi o ano em que houve o maior número de solicitações de reconhecimento de condição de refugiado, segundo a ACNUR: ultrapassou 80 mil solicitações (mais que o dobro de 2017). O aumento exponencial do deslocamento de venezuelanos e venezuelanas foi determinante, correspondendo a 61.681 das solicitações. Em segundo lugar está o Haiti (com 7 mil solicitações), seguido de cubanos (2.749), chineses (1.450) e bengaleses (947). Os estados com mais solicitações foram Roraima (50.770), Amazonas (10.500) e São Paulo (9.977). Os dados de 2018 totalizam 11.231 pessoas reconhecidas como refugiadas pelo Estado, sendo que, deste total, os sírios representam $36 \%$ da população refugiada com registro ativo no Brasil, seguidos dos congoleses, com 15\%, e angolanos, com 9\% (ACNUR, 2019).

A recém aprovada lei migratória brasileira (2017) repudia a xenofobia e a discriminação, desburocratiza processos de regularização, institucionaliza a política de vistos humanitários e amplia direitos dos imigrantes. Com relação aos refugiados, a política é regida pela Medida Provisória 820 (2018), que dispõe sobre "medidas de assistência emergencial para acolhimento a pessoas em situação de vulnerabilidade decorrente de fluxo migratório provocado por crise humanitária" (SPRANDEL, 2018, p. 57). Foi aprovada no auge da imigração 
de cidadãos venezuelanos e venezuelanas ao Brasil. Porém, apesar destes avanços, o processo de aprovação destas leis e medidas, segundo Sprandel, revelou igualmente a força das ideias racistas, xenófobas, agressivas e pragmáticas por parte dos parlamentares. Um exemplo das forças em debate na questão dos migrantes e refugiados no Brasil.

As tendências xenófobas no Brasil não estão apenas nos ambientes das bancadas parlamentares. Roberto Zwetsch (2017) lembra a "Marcha AntiImigração" acontecida na Avenida Paulista, em São Paulo, em 2017, a manifestar o ódio com relação a pessoas já marginalizadas na cidade, como palestinos, haitianos e venezuelanos. Além da xenofobia, as manifestações apresentavam corte racista e, podemos acrescentar, aporófobas. Isto mostra como a solidariedade da sociedade civil e das comunidades de fé são, como nos propõe o autor, importantes fatores de união, “ajuda mútua, fortalecimento das relações, das amizades, de reunir forças para enfrentar as dificuldades" (ZWETSCH, 2017, p. 135).

Neste cenário, digna de nota é a Cáritas do Brasil, estimulando e implantando alternativas de vida digna aos migrantes que chegam ao país, especialmente àqueles em situação de refúgio, mesmo antes de haver iniciativas governamentais para este fim. Ali, os refugiados são chamados “irmãos". Vale a pena resgatar o testemunho de Maria Cristina Morelli: "A Cáritas é o amor organizado da Igreja para o serviço aos mais pobres" (MORELLI, 2018, p. 169).

Em resumo, assistimos na última década um salto no número de refugiados e pessoas que buscam asilo em outro país. Lutam contra a indiferença e a oposição nos países receptores. Cercas e muros se espalham pelas fronteiras: EUA-México, Israel-Cisjordânia, Espanha-Marrocos em Ceuta e Melilla, Grécia-Turquia, Coreia do Norte-Coreia do Sul. Surgem iniciativas de apoio, mas são insuficientes.

Esta situação dramática implica perda de vidas humanas, sofrimento extremo no abandono forçado do país de origem e, como está no Estatuto do Refugiado da ONU, fundados temores de perseguição "por motivos de raça, nacionalidade, pertença a um determinado grupo social ou opiniões políticas" 
(ONU, 1951, p. 2). Estamos diante de um problema político, econômico, humanitário e teológico-espiritual.

\section{Causas da indiferença e do ódio aos migrantes e refugiados: duas perspectivas}

Trazemos aqui duas perspectivas de análise que nos parecem adequadas para a compreensão das origens antropológicas da indiferença, medo e mesmo ódio diante dos migrantes e refugiados: a aporofobia e a insegurança existencial.

\subsection{A aporofobia - rechaço aos pobres}

Devemos à filósofa Adela Cortina a criação do termo "aporofobia" e sua explicitação em Aporofobia, el rechazo al pobre (2018). Observa esta autora que, diante dos estrangeiros, há uma dupla reação. Se são turistas, a xenofilia - uma amizade, aproximação em relação aos xénos (estrangeiro, em grego); porém, se são imigrantes pobres e refugiados políticos, acontece a xenofobia. Diante disso, a autora se pergunta se isto trata-se de fato de xenofobia e chega a uma conclusão perturbadora: o que verdadeiramente causa o rechaço não é o fato de serem estrangeiros, mas o de serem pobres (p. 14).

A aporofobia - rechaço, aversão, desprezo, medo e mesmo ódio em relação ao aporos (pobre, em grego) - exclui quem não tem nada a retribuir do contrato político, econômico e social. Trata-se de uma tendência auto protetora, profundamente enraizada na história biossocial humana, na qual a reciprocidade acontece diante dos que são familiares ou diante dos que têm algo a oferecer em troca - evidentemente, não é o caso dos migrantes e refugiados. Termos genéricos, como “dignidade humana”, perdem sentido e pertinência sem nomear e indicar o rosto concreto daqueles contra os quais se nutre preconceitos, indiferença e ódio. Torna-se, assim, um desafio buscar os caminhos da dignidade dos aporoi.

Cortina (2018, p. 18-21) insiste em que é preciso dar nome às coisas para que elas não se transformem em ideologia naturalizada. A aporofobia, como todas as fobias (xenofobia, racismo, misoginia, homofobia, cristanofobia, 
islamofobia), acontece contra estranhos que não nos fizeram nada pessoalmente. Porém, em tempos de crise, o discurso e o delito de ódio obtêm enorme êxito, a exigir bodes expiatórios para acusar e responsabilizar pelos males vividos, pois, afinal, os que têm o poder não têm nada de positivo para oferecer. Além disso, as fobias grupais pressupõem uma assimetria social, a convicção da superioridade de alguns (por sua cor, origem social, condição econômica, etnia, país de origem, gênero etc.). E o cérebro, por sua vez, realiza interpretações tranquilizadoras.

A trágica saga do êxodo dos refugiados, que se une à dos imigrantes pobres, seria, neste sentido, um exemplo eloquente de aporofobia (CORTINA, 2018, p. 149). Esta se expressa no ódio dos discursos dos partidos e grupos populistas, dispostos a defender seus grupos frente a estranhos, com sangue e fogo. Eles se empenham em ignorar as melhores tradições morais da humanidade e insistem em fechar fronteiras, para que os que fogem de situações insuportáveis em seus locais de origem não possam aceder aos seus países. Trata-se de um dos maiores desafios do mundo globalizado.

Como dar passos no caminho da superação da aporofobia? A proposta de Cortina (2018, p. 156s) vai em duas direções, a do compromisso com a superação da pobreza e a da construção da sociedade cosmopolita, com cidadania universal, propósito mais diretamente relacionado a este artigo. Nesta construção, sobressai a virtude da hospitalidade como crucial na tradição ocidental, na qual o cristianismo joga importante papel. Trata-se de uma atitude pessoal, como um dever de hospitalidade. Mas, a este dever, corresponde um direito da hospitalidade, referido a instituições jurídicas, políticas e sociais, e às obrigações do Estado. Assim, a hospitalidade é tanto doméstica quanto institucional e universal, como dois lados da mesma moeda.

Porém, a exigência da hospitalidade vai além das leis e instituições e mais profundamente, do ponto de vista antropológico. Ela brota de uma hospitalidade incondicionada e do reconhecimento da alteridade como constitutiva de nós mesmos, nos diz Cortina, inspirada pelos filósofos Lévinas e Derrida.

A exigência ética incondicionada brota do reconhecimento da dignidade própria e alheia, do respeito a quem tem dignidade e não um simples preço. Brota também da 
solidariedade com as pessoas mais vulneráveis, [...] em tempos e lugares distintos, umas precisam de mais ajuda que outras para manter a vida, e vida de qualidade. (CORTINA, 2018, p. 167)

E, ainda mais profundamente, Cortina (2018, p. 168) colocará, como princípio ético fundante da superação da aporofobia, o reconhecimento de um vínculo originário entre os humanos, independente do que eles possam dar em troca. O desprezo, ódio e humilhação rompem a intersubjetividade, pertencimento e cuidado que nos fazem humanos. Por outro lado, a razão compassiva e cordial, cultivada em todos os níveis da educação e mediatizada pelas instituições, inclusive a família, estabelece vínculos intersubjetivos e é a única capaz de superar a aporofobia, visibilizada no rechaço aos migrantes e refugiados.

Adela nos ajuda a reconhecer a existência antropológica da aporofobia, forte tendência biossocialmente enraizada. O combate a ela se dá, por um lado, pelo cultivo de um mundo de valores, na ética do reconhecimento do vínculo humano e, por outro lado, através de leis, educação e instituições que sustentem e garantam uma cidadania universal.

\subsection{A insegurança existencial transferida para os órgãos de}

segurança

Vamos nos fixar em apenas uma ideia do instigante livro de Zygmunt Bauman, Estranhos à nossa porta (2017). Ao argumentar sobre as causas da rejeição aos estranhos por parte dos países que recebem os migrantes e refugiados, e consequente apoio a políticas segregadoras de segurança (a chamada "securitização"), Bauman (2017, p. 28) remete à ansiedade gerada pela insegurança existencial.

$O$ alto nível de insegurança existencial em que se encontram imersas nossas sociedades ocidentais se deve a forças globais, de natureza econômica e financeira, geradoras de um perturbador e humilhante sentimento de incerteza que corrói a confiança e a autoestima, solapa sonhos e planos de vida. Diante das forças poderosas da progressiva desregulamentação dos mercados de trabalho, da flexibilização da mão de obra, da perda da estabilidade da condição social e do derretimento da proteção contra a 
degradação social e negação da dignidade, sente-se a "impotência e incapacidade de resistir à debilitante precariedade de nosso lugar no mundo" (BAUMAN, 2017, p. 22). Forma-se um caldo de emoções, ansiedade, frustração, medo e ódio.

O problema é que esta insegurança existencial, difusa e sem um rosto que se responsabilize é, segundo Bauman (2017, p. 30-35), catalisada politicamente pelos governos conservadores e metamorfoseada em insegurança pública, resumida à ação policial contra o terrorismo e os estranhos que estão "à nossa porta”. As emoções negativas são despejadas sobre os que são diferentes, entre eles os migrantes e refugiados, considerados causa desta insegurança existencial, e não, também eles, produtos da mesma ou pior situação. Ao menos, eles têm rosto, são palpáveis e se encontram fisicamente perto — por isso podem ser objeto da indiferença, do medo e do ódio.

Transformado o problema da migração e dos refugiados em problema de segurança nacional e pessoal, as mentalidades são apaziguadas em seu dever de hospitalidade e acolhida, de reconhecimento da humanidade do “estranho" que implora a nossa compaixão.

A análise de Bauman nos ajuda a perceber a eficácia do discurso da segurança institucional como sucedâneo das políticas de emprego e distribuição de renda em escala planetária, inclusive no Brasil, onde as últimas eleições promoveram ao poder partidos e políticos comprometidos quase exclusivamente com o combate à criminalidade. A pergunta que fica é: até quando este "truque de mágica" (BAUMAN, 2017, p. 17), que é a "securitização" será capaz de mascarar o desemprego, a subutilização do trabalho e a insegurança existencial dos cidadãos?

\section{3. $O$ apelo de um Deus-hospitalidade}

A aporofobia e a metamorfose da insegurança existencial em problema de polícia, vistos acima, são duas poderosas causas da indiferença, medo e ódio ao migrante e ao refugiado. Trata-se de dois temas candentes da atualidade embora, evidentemente, não excluam outras explicações. Diante 
da virulência destas duas realidades, aparece o desconcertante convite de Deus à hospitalidade presente na tradição judaico-cristã, revelada de forma particular nas palavras e ações de Jesus de Nazaré. É o que veremos a seguir.

\subsection{A tradição judaica: proteção, interdição de abusos, hospitalidade} ao migrante

O povo hebreu não pode ser compreendido sem os deslocamentos geográficos por ele realizados. Vemos como, originalmente, era um povo nômade: "Meu pai era um arameu errante" (Dt 26,5). Por razões econômicas, migrou para o Egito, onde se tornou um povo escravizado (Gn 50,22; Ex 1,13); sua relação com a terra sempre fez parte de sua relação com Deus, a terra é um dom divino (Gn 12,1; Dt 26,1); o seu exílio para a Babilônia significou um trauma para todo o povo (2Rs 25,1-7; Sl 137) e o retorno ao país foi vivenciado com grande alegria (SI 126) (MITRA, 2018, p. 290).

Uma grande parte da história de Israel é de perseguição, exílio, violência e genocídio, fome e pobreza provocadas por desastres naturais (PILARIO; RECK, 2015, p. 664). Porém, Deus sempre se fez presente. Nos dois grandes exílios (em 721 a.C. o cativeiro assírio e, em 586 a.C., o cativeiro babilônico), fazse presente através dos grandes profetas Amós, Ezequiel, Jeremias e Isaías, provocando forte impacto na identidade e práxis do povo judeu, com repercussões igualmente na consciência cristã:

Quando um migrante vier morar junto a ti, na vossa terra, não o exploreis; esse migrante que mora entre vós, tratá-lo-eis como um nativo, com um de vós; amá-loás como a ti mesmo; pois vós mesmos fostes migrantes na terra do Egito (Levítico 19, 33-34).

Com tudo isso, a figura do migrante recebe, no Antigo testamento, um tratamento especial que inclui a hospitalidade e acolhida, a interdição à sua exploração e abusos e, até mesmo, a exigência de protegê-lo (MITRA, 2018, p. 290-291). O amor ao migrante chega a estar presente nos textos jurídicos de Levítico 19,33-34, "[...] amá-lo-ás [o migrante] como a ti mesmo". Ele deve ser amado como o próximo (Lv 19,18), que depende do amor fraterno dos demais, amor não apenas de sentimentos, mas constituído por práticas concretas, relações igualitárias e direitos iguais (GRENZER, 2017, p. 22-24). 
Acolhida e hospitalidade estão relacionadas com a revelação divina. No Antigo Testamento encontramos o episódio paradigmático de Abraão e Sara que recebem os três estrangeiros e, assim, acolhem o próprio Deus da promessa (Gn 18, 1-14).

A atitude de hospitalidade, acolhida e amor frente ao migrante torna-se matriz para se pensar as atitudes frente aos migrantes e refugiados de hoje, tanto na situação vista a partir do exilado quanto na situação de quem se vê impelido à hospitalidade (MITRA, 2018, p. 290). A consciência judaico-cristã se pergunta: quais serão os profetas a alentar o povo em seus exílios? A denunciar as lógicas excludentes e expulsoras dos modelos econômicos globalizados? A que é associada a figura do refugiado?

\subsection{Jesus Cristo: hospitalidade que provoca transformações} N. Reck, em seu criativo diálogo com D. Pilario (PILARIO; RECK, 2015, p. 663), observa que os milhares e milhares de pessoas em movimento, no nosso mundo globalizado, que buscam melhores condições de vida e de sustento de suas famílias podem ser comparados às "multidões" de que nos falam os evangelhos. Elas se movimentam, saem de seus lugares para ouvir a Jesus ${ }^{1}$. Em sua maioria, não o faziam por terem tempo livre ou por simples interesse, mas por buscarem alimento, ajuda e esperança. Interiormente, já se encontravam sem lugar. Estudos sobre o Novo Testamento descrevem estas multidões como pessoas que tinham perdido suas terras para os grandes senhores de terra, ou se encontravam endividadas por altos impostos, não tinham trabalho naquele local dominado pelo Império Romano. Pessoas sem nenhuma relevância social, enfermos, mendigos (PAGOLA, 2010, p. 326). Não se trata de minorias, mas da maioria social, necessitada e sem condições para se manter na vida.

Jesus acolhia as multidões com hospitalidade em seu meio. E mais, ajudava aquelas pessoas a construir solidariedade entre si, a manter-se de pé e atentas ao que Deus fazia entre elas. O lugar do Mestre era entre elas, e ele

\footnotetext{
1 São muitas as passagens, como mostra o autor: Mt 5,1;7,28; 8,1;8;18;9,36;11,7; 12,$15 ; 12,23$; 14,$14 ; 15,30 ; 19,2 ;$ Mc 2,2; 2,15; 3,7; 3,20; 4,1; 5,24; 6,33s; 8,1; 10,1; 15,41; Lc 5,19; 6,17; 8,4; 8,19; 8,$40 ; 14,25 ;$ Jo 6,$5 ; 7 ; 31 ; 8,30 ; 10,41 ; 12,9$.
} 
as incorporava em sua família, a família de Deus (Ef 2,19: "Não sois mais estrangeiros nem migrantes [...] sois da família de Deus"). Da mesma forma, ele mostra onde devem estar os cristãos: ao lado das multidões, dos milhares de refugiados, independentemente de sua religião, cultura ou etnia, sem esperar mudanças nas políticas oficiais de Roma.

Na parábola do bom samaritano (Lc 10,25-37), Jesus inaugura uma razão que parte da sintonia e identificação com o outro. Há uma empatia do samaritano com o homem ferido à beira do caminho e uma atuação concreta. Se observamos bem, aqui vemos o encontro de dois homens caídos: aquele que foi ferido e o samaritano, moralmente ferido e excluído. No sentimento e ação do samaritano, ambos são levantados, a evidenciar que Jesus vem trazer um caminho novo, que se empreende ao se buscar a vida, o único arquê possível, o princípio maior. Aqui é eliminada a barreira injusta entre a pessoa autóctone e o estrangeiro, e a humanidade torna-se o verdadeiro princípio de aproximação. As falsas condições que separam e segregam as culturas são convidadas a superar-se pelo encontro com aquele que salva e liberta (CUNHA, 2016, p. 25). Ele mesmo, Jesus, é “familiarizado com o sofrimento" (Is 53,3), o verdadeiro samaritano que vai ao encontro do desprovido de tudo para lhe oferecer, por sua solidariedade, um novo começo.

A hospitalidade se encontra dentre os ensinamentos de Jesus que tanto atraíam as multidões, e a tal ponto que acolher o pobre e o estrangeiro é acolher o próprio Cristo (Mt 25, 35.45) e responder ao convite do Deus hospitaleiro que nos acolhe no banquete do seu Reino, como Jesus mesmo fez em sua vida pública. Se observamos a perícope de Lc 19,1-10, vemos uma troca de hospitalidades. Jesus se auto convida à casa de Zaqueu (o excluído), que o acolhe com alegria - mas, na verdade, é o Mestre quem o acolhe na família de Abraão e o reintegra à comunidade dos salvos: "Hoje veio a salvação a esta casa, pois também ele é filho de Abraão" (Lc 19, 9) (THOMASSET, 2018, p. 270271). Particularmente, os momentos das refeições e, mais tarde, da eucaristia, são sinais da acolhida incondicional de Jesus e do convite à transformação da vida inspirada no exemplo do crucificado ressuscitado. As transformações de vida se dão no interior de um ambiente amoroso em que a iniciativa é do amor de Deus. 
Acolhida e hospitalidade são a maneira cristã de conviver e deixar-se transformar pelo outro - o migrante e o refugiado, mas também aquele que é política e culturalmente diferente. Constituem o ethos cristão para reagir à diversidade, atravessar fronteiras e derrubar muros.

\section{O apelo do Papa Francisco}

O discurso em Lampedusa impactou. Foi a primeira viagem apostólica do pontificado de Francisco e a ilha escolhida é ponto de passagem para milhares de imigrantes do Oriente Médio e do norte da África que tentam chegar à Europa mas que, muitas vezes, encontram o naufrágio e a rota da morte.

Em seu discurso, Francisco convidou ao despertar das consciências para fazer frente à "globalização da indiferença" (FRANCISCO, 2013) e chorou a morte daqueles por quem ninguém chora. Assim, visibilizou ao mundo que a Igreja, na pessoa de todos os cristãos, deve estar ao lado dos refugiados que buscam viver.

Neste processo de sensibilização ao diálogo e construção de pontes, e não de muros, Bauman cita o Papa Francisco como

[...] uma das pouquíssimas figuras públicas a nos alertar acerca dos perigos de seguir o gesto de Pôncio Pilatos, lavando nossas mãos diante das consequências de aflições e tribulações atuais, das quais somos todos, simultaneamente, em algum grau, vítimas e responsáveis (BAUMAN, 2017, p. 25).

Ao aprofundar nos aspectos centrais do Papa Francisco presentes nas Mensagens do Dia Mundial do Migrante e do Refugiado, de 2014 a 2018, Sanchez (2018) observa como o Pontífice apresenta um diagnóstico da crise migratória e diretrizes gerais para responder aos desafios gerados, e o faz em perspectiva de esperança e de ações concretas para um mundo melhor.

Francisco insere a questão dos migrantes e refugiados nos processos do mundo globalizado e interdependente, pautado por lógicas de desenvolvimento econômico e financeiro que admitem, convivem e mesmo alimentam o descarte humano, as perdas culturais e a destruição da natureza. A Encíclica Laudato si' apresenta esta crítica em vários momentos (FRANCISCO, 
2015, p. 88, n. 139; P. 113-117, ns. 189, 191 e 195). A crise migratória só pode ser compreendida na inter-relação com a crise socioambiental planetária, que atinge, de maneiras diferentes, as várias regiões do mundo, tanto aquelas de origem, de fronteira e as que acolhem os migrantes e refugiados.

Como consequência, ela apenas será tratada de forma justa e eficaz com uma mudança na lógica do desenvolvimento, que deve favorecer e atender às necessidades reais das pessoas e não descartá-las. Assim sendo, Francisco apela tanto para as políticas voltadas a favorecer a situação dos migrantes, refugiados e estrangeiros, garantindo-lhes dignidade, o que supõe trabalho, moradia, saúde e demais direitos, quanto à formação de uma nova consciência que anime a solidariedade. Igrejas, sistemas educacionais, religiões e meios de comunicação são chamadas a este processo de disseminação de valores como o respeito ao diferente e solidariedade com os que mais sofrem (SANCHEZ, 2018, p. 340).

O desenvolvimento dos valores e estruturas de solidariedade se enfrentam com desafios que parecem intransponíveis. Mas, como afirma Francisco na Laudato si', em sua proposta de unir a família humana e construir pontes entre as realidades, "as coisas podem mudar" porque "o Criador não nos abandona, nunca recua no seu projeto de amor, nem se arrepende de nos ter criado. A humanidade possui ainda a capacidade de colaborar na construção da nossa casa comum" (FRANCISCO, 2015, p. 16, n. 13).

\section{Indicações antropológicas para uma espiritualidade hospitaleira}

Diante de tudo o que foi dito, fica a pergunta de como caminhar rumo a uma espiritualidade hospitaleira, mais consciente dos graves entraves antropológicos presentes na sociedade política. Quatro pontos emergem do que foi traçado acima.

\subsection{Liberdade e identidade}

A caminhada do Israel migrante e miscigenado, bem como a convivialidade de Jesus poderiam nos fazer perguntar por nossa identidade. Onde estaria ela: atrás de nós, como origem, ou à nossa frente, interpelando a 
liberdade de escolha e de construção da própria identidade? (MITRA, 2018, p. 291). Teríamos que identificar nossa identidade com a origem, ciosos no fechamento? Estudiosos na área da sociologia percebem que culturas e religiosidades estão em movimento. As inter-relações culturais atravessam fronteiras e as matrizes culturais das sociedades de origem — incluindo as matrizes étnicas e religiosas — não são estáticas. Assim sendo, é possível falar de identidades abertas, que se conformam e constituem ao se inserirem em novos "entramados interculturais" (AMEIGEIRAS, 2016, p. 239). Somos como peregrinos neste mundo, a ponto de a patrística desenvolver o tema de que os cristãos são estrangeiros em sua pátria. A famosa Carta a Diogneto, de autor desconhecido, nos diz que "os cristãos habitam no mundo, mas não são do mundo" (GOMES, 1980, p. 158). Não haveria aí um princípio de liberdade e leveza para a saída de si, um encontrar-se no outro, o mesmo acontecendo na Igreja em saída?

\subsection{Trabalhar sentimentos: da rejeição ao sentir-com}

A construção de cercas e muros de separação nas fronteiras de países, bem como muros de autodefesa que evitam a diferença são "tentativas de barrar, não sentir a angústia" gerada por tudo e todos que remetem "ao desconhecido, ao diferente que é percebido como ameaçador e, portanto, provocador de um mal-estar" (BRÍGIDO; DAUBER, 2016, p. 97), observam profissionais da psicologia e da psicanálise. O sentimento de angústia não é só em relação ao outro, mas também a si mesmo. Trata-se de sentimentos opostos que evidenciam o paradoxo da situação de migração. Os sentimentos ocorrem igualmente com os migrantes ao chegarem ao lugar desconhecido. A parábola do samaritano, que comentamos, abre-nos a um mundo novo de possibilidade, atraente e desafiante.

Ora, o medo ao diferente pode ser encarado de outra forma. Ao invés de provocar uma paralisia, recusa do outro, medo persecutório e angústia, pode abrir espaço para sentir com o outro, reconhecer-nos pertencentes a uma mesma comunidade de vivos. É possível ser sensível ao outro: “é se deparando com o outro que é possível se reconhecer e experienciar o poder de ser; ouvir e ser ouvido, tocar e ser tocado, sentir-se sentindo" (BRíGIDO; 
DAUBER, 2016, p. 98). O reconhecimento do próximo em sua diferença acontece quando as especificidades não são percebidas como ameaças e se decide desenvolver a capacidade de sentir o sentir do outro.

\subsection{Aproximação de horizontes tão diferentes}

A construção de muros só leva à desolação da desconfiança. Trata-se de "políticas suicidas que armazenam explosivos para uma detonação futura" (BAUMAN, 2017, p. 23), um aprofundamento da humanidade em crise. A proposta que surge, no pensamento de Bauman, é a superação da tentação do isolamento e da separação e o empreendimento da conversação e do contato que levem a um processo de ampliação e fusão de horizontes, no sentido dado por Gadamer (1997, p. 326) e que o autor assume em sua reflexão (BAUMAN, 2017, p. 23 e 111). Neste caminho está a solidariedade entre os seres humanos. Ele exige o abandono da alienação mútua que recusa o diálogo, do silêncio que comporta uma autoalienação alimentada pela insensibilidade, desatenção, desprezo e indiferença. Desenvolvem-se diálogos que, de forma sempre incompleta, aproximam mundos de vida anteriormente separados e estranhos entre si e buscam acordos sobre alguns pontos.

Trata-se de uma outra lógica de se pensar a resolução de problemas e conflitos, em que a dignidade do outro é reconhecida e parte integrante da solução.

\subsection{Enriquecer-se com a riqueza dos pobres - superar a aporofobia}

É preciso escutar os testemunhos dos migrantes e refugiados, quer sejam muçulmanos, cristãos, judeus, sem religião, etc. Os refugiados externos e internos, em sua reorganização social, são agentes de transformação e cultura política que apontam um caminho de mudança e restauração do país e, por isso, podem ser ouvidos com mais atenção (MENDOZA, 2018, p. 248-250).

Estes refugiados são vítimas e é preciso escutar o grito das vítimas, leválos a sério e anunciar-lhes o Deus da vida, o Deus de Jesus que ama e liberta. Em um artigo que considera a violenta realidade centro-americana, em concreto San Salvador, Comabella Callizo, Schwab e Zechmeister (2017) 
lembram que as vítimas não têm uma voz entre outras, porque trazem consigo a autoridade de quem conhece o sofrimento por dentro e, com seu testemunho, dão razões para a vida e a esperança. São, por isso, "portadores e porta-vozes da vida" (2017, p. 270), testemunhos capazes de despertar a pessoa atenta da letargia e da passividade. Escutando com sensibilidade suas histórias de vida, podemos emudecer diante de sua livre e arriscada resistência que leva a lutar em meio a um verdadeiro mar de morte. Em suas histórias há “ilhas de vida", de humanização e de empatia humana, de companheirismo (2017, p. 272).

Urge ouvir os migrantes e refugiados com seus "golpes, feridas e cicatrizes" recebidos no caminho, que afetam a pessoa e a sua família (GONÇALVES, 2018, p. 46). Algumas feridas, invisíveis, permanecem abertas, atingem a alma, a identidade, a autoestima e, enfim, a própria humanidade. Graves são as situações com relação às crianças, como o descaso, a delegação de serviços degradantes e a agressividade nos espaços escolares. Indizível o abandono de idosos, massacrante a desqualificação de trabalhadores e trabalhadoras. Sem maiores dramas de consciências, migrantes e refugiados são removidos da condição humana comum.

Esta situação clama por maior envolvimento entre os atores em jogo, através de relações que transformam, reinvindica Carmen Lussi (2018, p. 188), ao se referir à relação entre os migrantes e as comunidades cristãs. Não se trata apenas de realizar doações, assisti-los, mas também de estar junto, orar com eles, num movimento real de abertura. Mesmo pessoas em situação de profunda vulnerabilidade são protagonistas, têm algo a dar, "um conhecimento, um testemunho, um serviço, em ensinamento" (LUSSI, 2018, p. 196). A relação com eles, a escuta de sua experiência espiritual é uma oportunidade para fé, uma dádiva que nos ajuda a superar a aporofobia — os migrantes e refugiados têm muito o que dar.

Saber receber dos pobres é abrir-se ao próprio Deus de Jesus Cristo. Eles são locus theologicus. Sua vulnerabilidade extrema nos tempos pós-modernos se transforma em subjetividade radicalmente aberta à transcendência, à Alteridade amorosa, que a "habilita a viver a sua exclusão sob a dinâmica de gratuidade" (CALDEIRA, 2018, p. 320) e esta doação, vivida sem ressentimento, 
revela a gratuidade da vida e do amor de Deus. Em certo sentido, e como já vem repetindo Carlos Mendoza (2015), os pobres nos salvam nesta revelação ativa do amor e do perdão de Deus. A aporofobia transforma-se em aporofilia e ação de graças.

\section{Conclusão}

A crise migratória está aí, avoluma-se e está longe de ser superada. As críticas impiedosas ao Papa Francisco, devido ao fato de ele defender a acolhida aos migrantes e refugiados, comprovam a força das lógicas de fechamento, racismo, aporofobia e eliminação autodefensiva da parte mais fraca, presentes nas formas de desenvolvimento econômico e político do atual mundo globalizado. Comprovam igualmente o caráter profético e evangélico do Pontífice.

Nossa reflexão, de maneira interdisciplinar, buscou articular a teologia com outras ciências, no intuito de aprofundar nas causas antropológicas da rejeição aos migrantes e refugiados. Reconheceu as contribuições da filósofa Adela Cortina que vê, na aporofobia, a raiz do problema e do sociólogo Zygmunt Bauman, que denuncia a redução ideológica da insegurança existencial a uma questão de segurança pessoal e estatal, a securitização. Com estes pensadores, vemos que rostos humanos concretos, vivendo situações dramáticas não são um caso de polícia ou um tema invisível de menor importância. A solidariedade, a democracia inclusiva e o reconhecimento do vínculo humano comum são alternativas benfazejas à indiferença e ao ódio.

A extensão do problema contrasta com a boa nova bíblica. Deus é hospitalidade e a ela convida. A Palavra de Deus fala de dentro da experiência de migração do povo hebreu, da própria família de Jesus (refugiada no Egito, cf. Mt 2,13-15), da experiência das multidões, do testemunho evangélico da convivialidade. A Palavra reforça e ilumina o caminho a seguir e inspira rumos para novas relações. Numa espiritualidade hospitaleira, a identidade própria se deixa enriquecer pela alheia, os sentimentos de rejeição são reorientados ao interesse pelo sentir do outro, os diferentes horizontes são aproximados pela conversação e os pobres são reconhecidos em sua riqueza, a transformar aporofobia em aporofilia e ação de graças. 


\section{Referências}

ACNUR-Alto Comissariado das Nações Unidas para Refugiados. Dados sobre refúgio, 19 de junho de 2019. Disponível em: <https://www.acnur.org/portugues/dados-sobrerefugio/dados-sobre-refugio-no-brasil/>. Acesso em: 25 jun. 19.

AMEIGEIRAS, A. R. Las creencias religiosas de los migrantes o la religiosidad en movimiento. Stromata, San Miguel, Argentina, v. XLLII, n. 2, p. 231-241, jul./dic. 2016.

BAUMAN, Z. Estranhos à nossa porta. Rio de Janeiro: Zahar, 2017.

BRíGIDO, M. A. da S.; DAUBER, L. Migrantes. Considerações sobre os sentimentos frente ao estrangeiro. Humanística e Teologia, Porto, v. 37, n. 2, p. 87-99, dez. 2016.

CALDEIRA, C. Da Europa à América Latina: a vulnerabilidade como locus theologicus. Perspectiva Teológica, Belo Horizonte, v. 50, n.2, p. 307-323, mai./ago. 2018.

COMABELLA CALLIZO, J.; SCHWAB, B. J.; ZECHMEISTER, M. Escuchar el grito de las víctimas. Impulsos desde la teología de la liberación. Revista Latinoamericana de Teología, San Salvador, v. XXXIV, n. 102, p. 251-279, sep./dic. 2017.

CORTINA, A. Aporofobia, el rechazo al pobre. Un desafio para la democracia. Barcelona/Buenos Aires / México: Paidós, 2018[2017].

CUNHA, J. T. Refugiados e migrantes na fronteira da vida. Humanística e Teologia, Porto, v 37, n. 2, p. 19-35, dez. 2016.

GADAMER, H.-G. Verdade e método. Traços fundamentais de uma hermenêutica filosófica. Petrópolis: Vozes, 1997.

GOMES, C. F. Antologia dos Santos Padres. 2. Ed. São Paulo: Paulinas, 1980.

GONÇALVES PATRICIO, J. P. Migração forçada na África subsaariana: alguns subsídios sobre os refugiados em Moçambique. REMHU-Revista Interdisciplinar da Mobilidade Humana. Migrações na África: sujeitos, impactos e desafios, Brasília, v. 26, n. 54, p. 1130, dez. 2018.

GONÇALVES, A. J. Migrantes: feridas e cicatrizes. Panorama nacional e internacional das migrações. In: POSSANI, L. de F. P.; FRANCO, C. B. (Orgs). Por uma cidade acolhedora. Somos todos migrantes. $32^{\circ}$ Curso de Verão. São Paulo: Paulus, 2018. p. 21-56.

GRENZER, M. A proposta ímpar do amor ao imigrante (Lv 19,33-34). In: MOREIRA, Alberto da Silva (Org.). Religião, migração e mobilidade humana. Goiânia: PUC-Goiás, 2017. p. 13-30.

LUSSI, C. Encontro transformante. Desafios e oportunidades da relação Igreja local e as migrações internacionais. Espaços. Revista de Teologia e cultura. Teologia e Mobilidade humana, São Paulo, ITESP, v. 26, n. 2, p. 185-207, 2018. 
MENDOZAÁLVAREZ, C. Deus ineffabilis: una teología posmoderna de la revelación del fin de los tiempos. Barcelona: Herder/Universidad Iberoamericana, 2015.

MENDOZA, P. El desplazamiento forzado en Colombia. Concilium, n. 375, p. 241-250, abr. 2018.

MITRA, A. Chronique louvaniste: XIVe coloque Gesché: “Migrant ou la vérité devant soi: un enjeu d'humanité" (30 et 31 octobre 2017). Revue théologique de Louvain, Lovaina, v. 49, n. 2, p. 290-293, abr./jun. 2018.

MORELLI, M. C. Acolhimento e apoio aos migrantes e refugiados. Centro de Referência para Refugiados, Caritas Arquidiocesana de São Paulo. In: POSSANI, L. de F. P.; FRANCO, C. B. (Orgs). Por uma cidade acolhedora. Somos todos migrantes. $32^{\circ}$ Curso de Verão. São Paulo: Paulus, 2018. p.163-169.

ONU. Convenção relativa ao Estatuto dos Refugiados, 1951. Disponível em: <https://www.acnur.org/fileadmin/Documentos/portugues/BDL/Convencao_relativa _ao_Estatuto_dos_Refugiados.pdf>. Acesso em: 25 jun. 19.

PAGOLA, J. A. Jesus: aproximação histórica. Petrópolis: Vozes, 2010.

PAPA FRANCISCO. Homilia. Lampedusa, 8 de julho de 2013. Disponível em: <https://w2.vatican.va/content/francesco/pt/homilies/2013/documents/papafrancesco_20130708_omelia-lampedusa.html>. Acesso em: 15 abr. 2018.

PAPA FRANCISCO. Carta Encíclica Laudato si'. Sobre o cuidado da casa comum. Brasília: CNBB, 2015.

PILARIO, D.; RECK, N. Refugiados. Una conversación entre Danny Pilario (Filipinas) y Norbert Reck (Alemania). Concilium, n. 362, p. 151-159, sep. 2015.

SANCHEZ, W. L. Francisco e as migrações: um olhar a partir das mensagens para o dia mundial do migrante e do refugiado (2014 a 2018). Perspectiva Teológica, Belo Horizonte, v. 50, n. 2, p. 325-342, mai./ago. 2018.

SPRANDEL, M. A. Leis migratórias e conservadorismo parlamentar no Brasil: o caso da Lei 13.445, de 2017. ACNUR-Alto Comissariado das Nações Unidas para Refugiados; IMDH-Instituto Migrações e Direitos Humanos. Cadernos de Debates Refúgio, Migrações e Direitos Humanos, v. 13, n. 13, p. 37-59, dez. 2018. 
THOMASSET, A. La frontière à l'épreuve de l'hospitalité. Perspectiva Teológica, Belo Horizonte, v. 50, n.2, p. 263-275, mai./ago. 2018.

ZWETSCH, R. E. Migração, interculturalidade e resiliência: desafios para a democracia, os direitos humanos e as comunidades religiosas. In: MOREIRA, A. da S. (Org.). Religião, migração e mobilidade humana. Goiânia: PUC-Goiás, 2017. p. 125-139.

RECEBIDO: $28 / 07 / 2019$

APROVADO: $16 / 04 / 2020$
RECEIVED: 07/28/2019

APPROVED: 04/16/2020 